\author{
O Iga Semeshko, Julia Saribekova, Tatiana Asaulyuk and \\ Sergey M yasnikov
}

\title{
THE IN FLUEN CE OF ELECTRICAL DISCHARGE NON LINEAR BULK CAVITATION ON THE STRUCTURAL AND CHEMICAL CHANGES IN WATER DURING THE WOOL FIBER BLEACHING
}

\author{
Kherson National Technical University \\ 24, Berislavske road, 73008 Kherson, Ukraine \\ solgaya@gmail.com
}

Received: February 27, 2013 / Revised: May 30, 2013 / Accepted: September 30, 2013

() Semeshko O., Saribekova J., Asaulyuk T., Myasnikov S., 2014

\begin{abstract}
The influence of the electric-discharge treatment on changes in the physical and chemical properties of water has been investigated. It is shown that the influence of the electrical discharge nonlinear bulk cavitation changes the structure of water as well as the formation of free radicals and hydrogen peroxide. The electric-discharge treatment increases the whiteness of wool due to the changes in water properties.
\end{abstract}

Keywords: electric-discharge treatment, cavitation, the properties of water, bleaching.

\section{Introduction}

Currently existing technologies for preparation of woolen textiles have large power consumption and often result in unwanted damage of the fiber during processing. It is possible to improve the quality and reduce the cost of production by intensifying the technological processes of finishing in several ways: by the influence on the material, by changing the properties of the medium in which the treatment implements, and in both directions simultaneously.

Analysis of the scientific-technical and patent information shows that one of the most effective ways of solving problems is increasing of the technological process speed and equipment performance, reducing its energy and materials, and improving product quality through the pulsed power influence on the treated materials [1-5]. Such processes include the high-voltage electric pulse discharge in a liquid, which is a practical application in various industrial processes and was first proposed by the Soviet scientist L. Yutkin, who called this phenomenon the electro-hydraulic effect [1].
The essence of this phenomenon is that while placing an especially crafted pulsed electric discharge inside the liquid in an open or closed vessel so that around the area of its formation ultra-high water pressure occurs, which can perform useful mechanical work, and is accompanied by a set of physical and chemical phenomena [1]. The main effective factor is the effect of electrical cavitation.

Today, ultrasonic and hydrodynamic cavitation is studied most of all. However, these methods for generating cavitation are not widely used in the finishing industry. In our opinion, for the textile industry the application of electrical cavitation which has a number of unique features is promising [1, 2, 6-9]. Electric-discharge nonlinear bulk cavitation (EDNBC) is the most powerful form of the cavitation, which has no analogues in building radiation power because shock waves are the generator of cavitation, interacting with the environment rather than a solid body.

Electric-discharge processes are often carried out in water, as it is proven that in water there is the most intensive development of cavitation [9].

According to the authors $[2,3,10,11]$ during the cavitation treatment of water the changes occur in its structure by mechanisms conditioned by the cavitation theory and the theory of water structure and the spatial distribution of its molecules. However, until now the general theory of water structure does not exist. It is known that water belongs to the liquids with anomalous properties that are different from those of liquids consisting of monatomic or polyatomic symmetrical spherical molecules. The presence of intermolecular hydrogen bonds contributes to the emergence of the spatial structure of water. Moreover, its molecules do not "stick" close to each other and there are significant voids between them. The cause of the void formation is a 
particular form of water molecules and the spatial direction of the hydrogen bonds that hold the molecules over large distances and form a loose structure.

One of the most plausible theories of the water structure, which promotes the concept of hydrophobic interactions, is the theory of flickering clusters [12-18]. The essence of this theory is that the gap and the formation of intermolecular bonds between water molecules depend not only on the properties of individual molecules, but also on the population of molecules, the associate of the polymer (cluster), which is formed by weaker hydrogen bonds between molecules - the associate members. If a molecule of water under the external influence leaves the associate, breaking the hydrogen bond, then the further expansion of the associate becomes easier. So both the formation and destruction of clusters with an ordered structure are possible. This phenomenon characterizes water as a dynamic two-phase system with associates and free molecules between them, which are generally held by Vann der Waals forces (Fig. 1) [12].

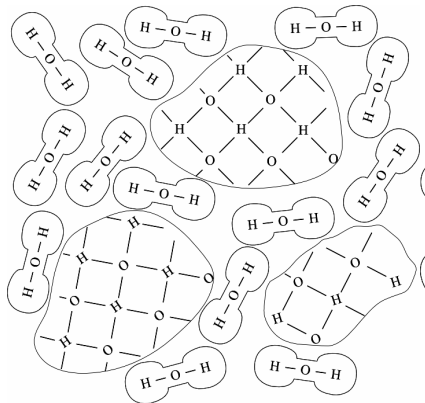

a)

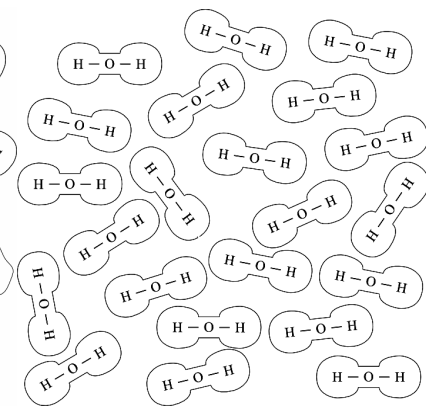

b)
Fig. 1. The structure of water: two-phase structure of water (a) and structured water (b)

It is assumed that it is possible to break intermolecular bonds in clusters, i.e. to change the structure of water under the influence of an external cavitation field.

Data from numerous studies that are presented in the scientific literature $[2-4,7,8,19,20]$ indicate that during the cavitation treatment of water, the structural changes and the chemical transformations accompanied by the formation of free radicals and hydrogen peroxide are taking place at the same time. Therefore, the assertion that the effect of the cavitation field on the water can be explained only by cavitational mixing water is not valid.

The process of free radicals formation and their recombination in water under the effect of the cavitation process can be represented by the following overall reaction [3]:

$$
\mathrm{H}_{2} \mathrm{O} \Rightarrow \mathrm{H}_{2} \mathrm{O}, \mathrm{H}^{\mathrm{c}}, \mathrm{OH}^{\mathrm{c}}, \mathrm{H}_{2}, \mathrm{HO}_{2}^{\mathrm{c}}, \mathrm{H}_{2} \mathrm{O}_{2}
$$

Thus, we can state that the accumulated knowledge about the phenomenon of cavitation in fluids, particularly water, is enough to be applied in practice.
However, the widespread adoption of EDNBC method in the textile industry is hampered by a lack of systematic studies providing a complete picture about the patterns of changes in fluid properties and processed materials during electric-discharge treatment.

In connection with the foregoing, the objective of this study was to investigate the changes in the properties of water during electric-discharge treatment and its effect on the whiteness of wool fibers.

\section{Experimental}

Electric-discharge treatment was carried out on a laboratory setup (Fig. 2), which was developed by the Institute of Pulse Processes and Technologies NAS of Ukraine (Nikolayev), together with scientists from Kherson National Technical University.

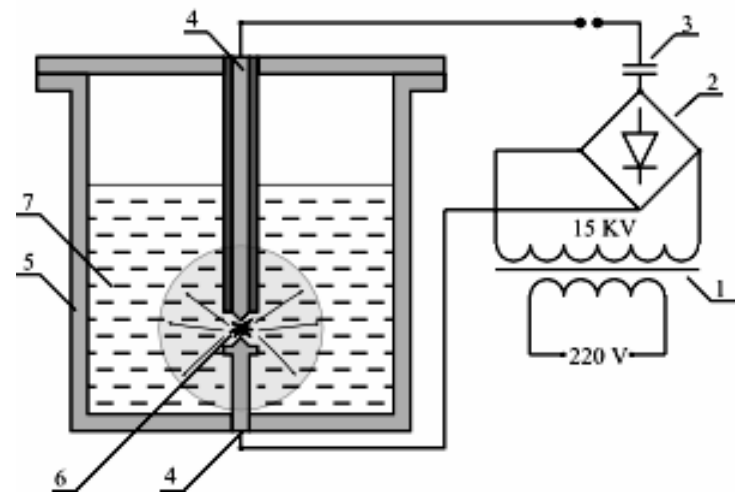

Fig. 2. Schematic diagram of the laboratory setup: step-up transformer (1); diode bridge (2); capacitor (3); electrodes (4); reactor vessel (5); zone of discharge (6) and liquid (7)

Equipment performances are presented in Table 1.

Table 1

\section{Equipment features}

\begin{tabular}{|l|c|}
\hline \multicolumn{1}{|c|}{ Parameter } & Value \\
\hline Mains current & AC, single phase \\
\hline Frequency, $\mathrm{Hz}$ & $50 \pm 0.1$ \\
\hline Supply voltage, $\mathrm{V}$ & $220 \pm 22$ \\
\hline Efficiency, at least & 0.7 \\
\hline Operating voltage, $\mathrm{kV}$ & 15 \\
\hline Pulse repetition frequency, $\mathrm{Hz}$ & 1.5 \\
\hline Capacity of the capacitor battery, uF & 0.5 \\
\hline Power consumption, $\mathrm{W}$ & 400 \\
\hline
\end{tabular}

Filtered tap water with varying exposure time from 30 to $300 \mathrm{~s}$ was exposed to the electric-discharge treatment.

Indirect evidence that structural changes of water occur during its electric discharge is micrographs of ice crystal structure. The experiment was conducted by the 
method of the Japanese scientist M. Emoto to confirm the structural changes in water under the influence of EDNBC. We studied photographs of frozen water to find out the change of the ice crystal structure.

Radical concentration was determined by the consumption of oxalic acid, which interacts only with free radicals, as follows:

$$
\mathrm{HOOC}-\mathrm{COOH}+2 \mathrm{R}^{\circ} \Rightarrow \mathrm{ROOC}-\mathrm{COOR}+\mathrm{H}_{2}
$$

Since the oxalic acid is oxidized only by radicals, the amount of spent $\mathrm{COO}^{-}$ion can be equated to the number of formed radicals [10, 21-23].

The concentration of hydrogen peroxide, formed under the influence of EDNBC, was determined by iodometric titration [10, 21-23].

Electric-discharge treatment was conducted within the time interval from 30 to $300 \mathrm{~s}$ to determine the effect of EDNBC on the wool fiber. Semi-thin wool in the form of brushed belt was treated. Then the whiteness of wool fiber was determined using "Spekol-11" spectrophotometer.

\section{Results and Discussion}

Micrographs of the crystalline structure of ice may serve as the indirect evidence that structural changes may occur during water electric-discharge treatment. Micrographs of ice from water before and after the electric-discharge treatment are shown in Fig. 4.

Fig. 3. Micrographs of ice structure: under the influence of electricdischarge treatment (a) and without treatment (b)

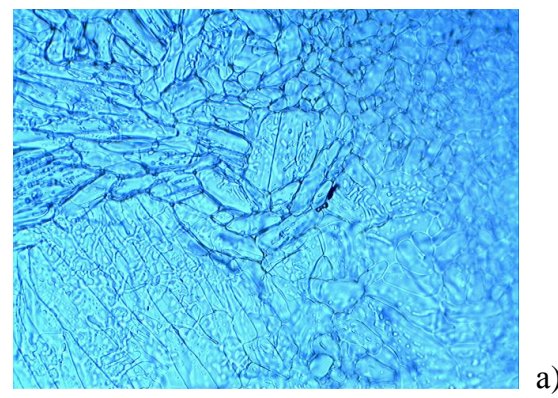

a)

The presented images show that ice of water exposed to cavitation has characteristic streaks of regular shape, unlike the ice of untreated water, which has the structure of irregular polyhedral, confirming the presence of structural changes in water under the action of cavitation.

Considering that the efficiency of the bleaching will depend on the amount of free radicals formed and hydrogen peroxide in electric-discharge treatment, the studies were conducted to determine these parameters.

Figs. 4 and 5 show the dependence of the free radicals concentration change and hydrogen peroxide on the time of the electric-discharge treatment.

The obtained curves shown in Figs. 4 and 5 suggest that the concentration of radicals and hydrogen peroxide increases with the increase of treatment time. Within $60 \mathrm{~s}$ of processing their concentration increases linearly but with a further increase in the duration the concentration raises slightly.

The process of textile bleaching, including that of the wool fiber, is traditionally carried out using hydrogen peroxide. It decomposes in a bleaching solution via the radical mechanism with the formation of reactive oxygen species and radical products that are able to oxidize colored substances of fibrous materials, thus increasing their whiteness [23]. In the finishing production special attention is given to the whiteness index, because from technological point of view, the most valuable products are bleached textiles because of the possibility of dyeing in any color.

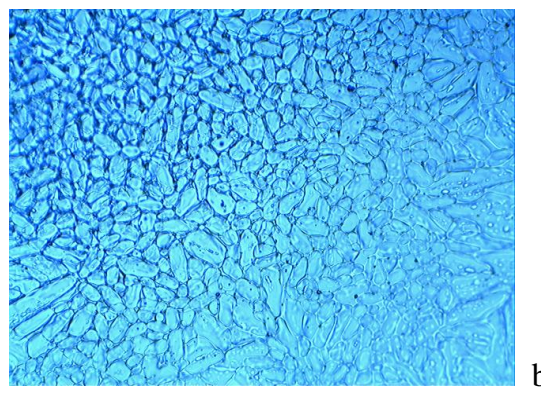

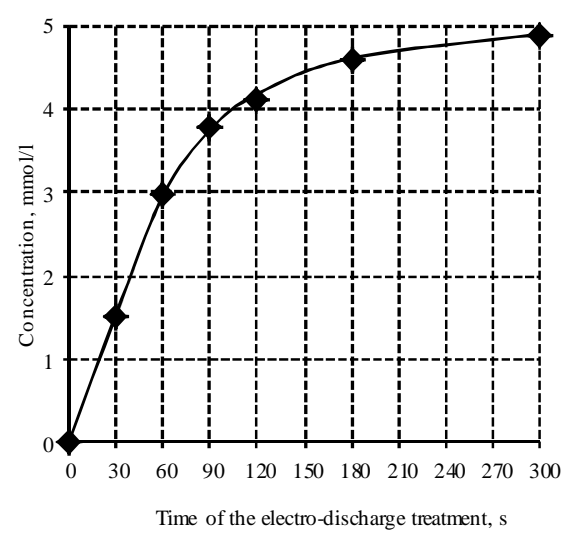

Fig. 4. The kinetics of free radicals formation in the electric-discharge treatment

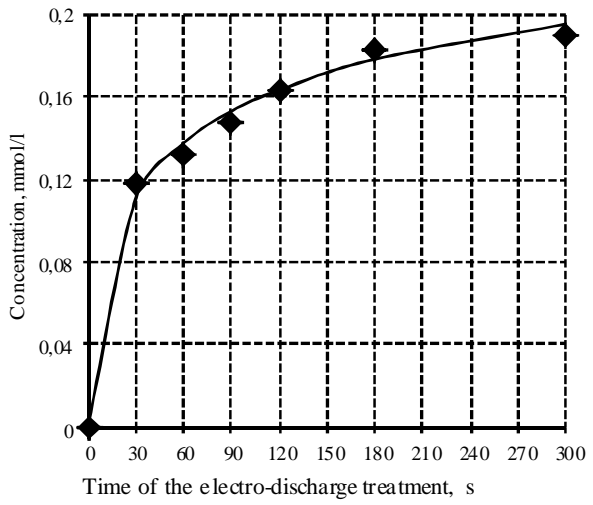

Fig. 5. Formation kinetics of hydrogen peroxide in the electric-discharge treatment 
In order to determine the impact formed under the influence of EDNBC free radicals and hydrogen peroxide on the whiteness of a wool fiber, electricdischarge treatment was carried out.

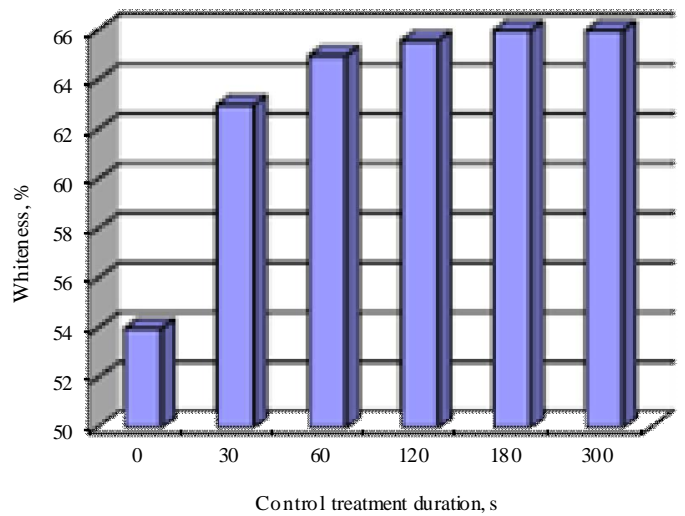

Fig. 6. The dependence of wool whiteness on the electric-discharge treatment time

Analysis of the data presented in Fig. 6, indicates that the most intense bleaching process is performed within the first $30 \mathrm{~s}$ of electric-discharge treatment. With increasing treatment time the rate of whitening decreases slightly, as indicated by slight changes in the whiteness index. Comparison of whiteness index after 180 and $300 \mathrm{~s}$ of EDNBC exposure shows that whiteness does not change. Thus, we can conclude that in order to increase the wool fiber whiteness, its electric-discharge treatment over 180 seconds is inappropriate.

\section{Conclusions}

The result of the study has revealed that the electric-discharge treatment leads to structural and physico-chemical changes in water. The presence of free radicals and hydrogen peroxide, generated by cleavage of water, contributes to the rise of whiteness of wool fibers.

\section{Acknowledgements}

This work was performed in the industrial research laboratory of Kherson National Technical University (Ukraine) in the research project "Development of Innovative Clean Technologies and Creation of Experimental and Industrial Equipment for the Modified Wool Fiber", (state registration number 0112U000776).

\section{References}

[1] Yutkin L.: Elektrogidravlicheskiy Effekt i ego Primenenie v Promyshlennosty. Mashynostroenie, Leningrad 1986.

[2] Promtov M.: Mashiny i Apparaty s Impulsnymi Energetycheskimy Vozdeystviyami na Obrabatyvaemye Veshchestva. Mashynostroenie-1, Moskwa 2004.
[3] Viten'ko T.: Gidrodynamichna Kavitatsiya u Masoobminnyh, Khimichnyh i Biologichnyh Procesah. Vydav. Ternopil'skogo Derzh. Techn. Univ. im. I. Puluya, Ternopil' 2009.

[4] Naugol'nyh K. and Roy N.: Elektricheskie Razryady v Vode. Nauka, Moskwa 1971.

[5] Krasnyans'ka O.: Visnyk Hmel'nits'kogo Nats. Univ., 2005, 5, 101.

[6] Kardashev G.: Fizicheskie Metody Intensifikatsii Processov Khimicheskoy Tehnologii. Khimiya, Moskwa 1990.

[7] Drozhzhin A., Karpov D. and Teslenko B.: 8 Mezhdunarod. Nauchn. Konf., Rossiya, Sankt-Peterburg 2006, 164.

[8] Ushakov V.: Impul'snyj Elektricheskiy Proboy v Zhidkosti. Izd. Tomskogo Univ., Tomsk 1975.

[9] Malyushevskaya A.: PhD thesis, Hersons'kij Nazion. Techn. Univ., Herson 2005.

[10] Piskarev I., Solov'ev G., Karelin V. et al.: Khimiya Vysokikh Energiy, 2005, 39, 228.

[11] Ivchenko V. and Esikov S.: Gidrodinamika Bol'shikh Skorostey. KrPI, Krasnoyarsk 1989.

[12] Nemethy G. and Scheraga H.: J. Chem. Physics, 1962, 36, 3382.

[13] Nemethy G.: J. Phys. Chem., 1962, 66, 1773.

[14] Zollinger H.: J. Soc. Dyers and Colour, 1965, 81, 345.

[15] Rattee I.: J. Soc. Dyers and Colour, 1974, 90, 367.

[16] Meggy A.: J. Soc. Dyers and Colour, 1950, 66, 505.

[17] Zatsepina G.: Svoystva i Struktura Vody. Izd. Moskovskogo Univ., Moskwa 1974.

[18] Eyzenberg D. and Kautsman V.: Struktura i Svoistva Vody. Gidrometeoizdat, Leningrad 1975.

[19] Volkov V., Bekker V., Katrakov I. et al.: Izv. Altayskogo Gos. Univ., 2007, 55, 63

[20] Shevchuk L., Aftanaziv I. and Strogan O.: Avtomatizacija Vyrobnychyh Procesiv u Mashinobuduvanni ta Priladobuduvanni, 2011, 45, 374.

[21] Shevchuk L., Aftanaziv I. and Strogan O.: Visnyk Nats. Techn. Univ. "HPI", 2011, 43, 12.

[22] Shevchuk L., Aftanaziv I., Koval' I. et al.: Vostochno-Evrop. Zh. Peredovykh Techn., 2012, 56, 17.

[23] Emoto M.: Poslaniya Vody: Taynye Kody Kristallov L'da. Sofia, Moskwa 2005.

[24] Aristova N. and Piskareva I.: Zh. Techn. Fiziki, 2002, 72, 41.

[25] Domracheev G., Rodygin Yu. and Selivanovskiy D.: Doklady Akad. Nauk, 1993, 329, 35.

[26] Viten'ko T. and Gumnitskiy Ya.: Khimiya i Techn. Vody, 2007, 29, 422 .

[27] Krichevskiy G.: Khimicheskaya Technologiya Tekstil'nykh Materialov, v.1. Izd. Moskovskogo Gos. Univ., Moskwa 2001.

\section{ВПЛИВ ЕЛЕКТРОРОЗРЯДНОЇ НЕЛІНІЙНОЇ ОБ'ЄМНОЇ КАВІТАЩІЇ НА СТРУКТУРНІ ТА ХІМІЧНІ ЗМІНИ ВОДИ У ПРОЦЕСІ ВИБІЛЮВАННЯ ВОВНЯНОГО ВОЛОКНА}

Анотація. Досліджено вплив електророзрядного оброблення на зміну фізико-хімічних властивостей води.

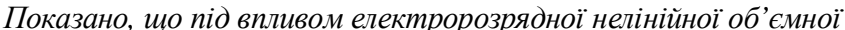
кавітачії відбувається зміна структури води, а також утворення вільних радикалів та пероксиду водню. Встановлено, що під впливом електророзрядного оброблення внаслідок зміни властивостей води підвищується білизна вовни.

Ключові слова: електророзрядне оброблення, кавітація, властивості води, вибілювання. 